\title{
PENGEMBANGAN PERANGKAT PENILAIAN KINERJA DAN SIKAP PADA PRAKTIKUM TITRIMETRI DAN GRAVIMETRI SMK-SMTI MAKASSAR
}

\author{
Widya Dwi Anggraini, Ramlawati ${ }^{1}$, Muhammad Anwar ${ }^{2}$ \\ 1,2 Dosen PPs Pendidikan Kimia Universitas Negeri Makassar \\ Email: widyadwianggraini@ymail.com
}

\begin{abstract}
ABSTRAK
Penelitian ini bertujuan untuk menghasilkan perangkat penilaian pada praktikum titrimetri dan gravimetri meliputi penilaian kinerja dan sikap yang valid, reliabel, dan praktis. Dengan melibatkan satu kelas sebagai subyek uji coba yang terdiri dari 33 orang peserta didik serta 4 orang guru. Kevalidan diperoleh berdasarkan penilaian pakar terhadap perangkat penilaian kinerja dan sikap yang dikembangkan, reliabilitas diperoleh dari nilai koefisien Alpha Cronbach berdasarkan program SPSS, dan kepraktisan diperoleh dari nilai angket respon guru terhadap perangkat penilaian kinerja dan sikap yang dikembangkan. Langkah pengembangan ini terdiri dari lima langkah yakni (1) investigasi awal yang dilakukan melalui kegiatan mengidentifikasi informasi, analisis informasi, membatasi masalah dan merencanakan kegiatan lanjutan; (2) perencanaan yang dilakukan melalui kegiatan perancangan penilaian kinerja dan sikap dalam bentuk penyusunan kisi-kisi penilaian kinerja maupun sikap; (3) realisasi atau konstruksi yang dilakukan dengan pembuatan draft awal penilaian kinerja dan sikap; (4) evaluasi, tes, dan revisi dilakukan dengan validasi isi; serta (5) implementasi dilakukan dengan kegiatan uji coba terbatas. Instrumen yang digunakan adalah lembar validasi untuk mengukur kevalidan dan reabilitas serta angket respon guru untuk mengukur kepraktisan. Hasil penelitian menunjukkan bahwa perangkat penilaian kinerja dan sikap pada praktikum titrimetri dan gravimetri memenuhi kriteria valid, reliabel, dan praktis. Rata-rata kevalidan, reliabilitas, dan kepraktisan perangkat penilaian berturut-turut adalah 0,$965 ; 0,807$; dan 64,87 berdasarkan penilaian kedua validator dan berdasarkan uji coba yang dilaksanakan pada peserta didik Jurusan Kimia Industri SMK-SMTI Makassar
\end{abstract}

Kata kunci: pengembangan, penilaian, kinerja, sikap, praktikum.

\begin{abstract}
This research aims to produce performance assessment and attitudes tools on titrimetric and gravimetric Laboratory which valid, reliable, and practical. Validity based on judgment of expert on performance assessment tools and attitudes that are developed, reliability obtained from Alpha Cronbach coefficient values based SPSS, and practicality is obtained from the value of teachers' questionnaire responses and performance assessment tools developed attitude. This development step consists of five steps: (1) preliminary investigation with excute identify information, analyze information, to limit the problem, and plan continuation activity; (2) design with excute design performance and attitude assessment in form matriks performance and attitude assessment; (3) realization or construction with excute to make first draft; (4) test, evaluation, and revision with excute to judgement of ekspert; and (5) implementation with excute to trials carried out. The instrument which used are classifier for paper validation for measure validity and reability as well as teachers' questionnaire responses for measure practicality. The results showed that the performance assessment and practical attitude on titrimetric and gravimetric meet the criteria of valid, reliable, and practical. Mean valid, reliable, and practical in sequence are 0,$965 ; 0,807$; and 64,87 assessments is based on
\end{abstract}


both validator and based on trials carried out at the Department of Industrial Chemistry students SMK-SMTI Makassar.

Keywords: development, assessment, performance, attitude, practice.

\section{PENDAHULUAN}

Dinamika pembangunan Indonesia sebagai negara berkembang berusaha meningkatkan SDM dengan cara meningkatkan mutu pendidikan. Lulusan SMK merupakan bibit SDM penting sehingga mutu lulusan ini perlu ditingkatkan. Peningkatan mutu lulusan ini tidak lepas dari pembinaan kompetensi melalui kegiatan pembelajaran yang diberlakukan. Salah satu mata pelajaran yang mengembangkan kompetensi peserta didik adalah Praktikum Dasar Kerja Laboratorium.

Praktikum Dasar Kerja Laboratorium merupakan mata pelajaran bidang produktif yang mengacu pada Standar Kompetensi Kerja Nasional Indonesia yang bertujuan membekali peserta didik konsep dan prinsip dasar kerja laboratorium serta memiliki keterampilan mengembangkan pengetahuan, dan sikap percaya diri sebagai bekal kesempatan melanjutkan pendidikan pada jenjang yang lebih tinggi serta mengembangkan ilmu pengetahuan dan teknologi (Kemendikbud, 2014).

Pelaksanaan pembelajaran terkait dengan proses penilaian. Penilaian menurut Husamah (2013) dan Arends (2008) digunakan sebagai bahan refleksi untuk mengetahui perkembangan pencapaian peserta didik, sehingga penilaian merupakan bagian penting dari pembelajaran. Teknik dan alat penilaian seharusnya disesuaikan dengan tujuan dan sasaran penilaian, situasi, dan kondisi lingkungan, serta kompetensi dasar seperti yang telah tercantum pada kurikulum (Ruslan, 2005).

Pada kegiatan praktikum proses penilaian dapat dilaksanakan untuk melihat kemampuan peserta didik dalam melakukan praktikum, yakni dalam hal pengetahuan, sikap, dan keterampilan secara simultan. Pemberian soal saat responsi merupakan penilaian yang berorientasi pada hasil pembelajaran. Penekanan penilaian praktikum sesungguhnya justru terletak pada proses pengambilan keputusan yang ditunjukkan pada kinerja pada saat praktikum. Pelaksanaan praktikum tidak hanya menyangkut pengetahuan tentang teori maupun keterampilan dalam mengaplikasikan dan membandingkan teori tersebut dalam bentuk kerja, namun juga memerlukan respon sikap dalam melakukan praktikum. Kegiatan praktikum dapat memupuk sikap ilmiah yang dapat menjadi salah satu indikator keberhasilan proses pembelajaran kimia.

Kinerja maupun sikap peserta didik adalah dua hal yang bersifat kualitatif dan sulit untuk diukur, oleh karena itu diperlukan instrumen penilaian harus menyertakan pembobotan rinci yang dapat memetakan kemampuan peserta didik dalam melakukan sesuatu. Guru dapat menilai kompetensi keterampilan menggunakan tes praktik, proyek, maupun penilaian portopolio (Kemendikbud, 2013). Penilaian seperti ini menurut Kunandar (2014) biasanya dilakukan melalui instrumen pengamatan menggunakan skala rating dan daftar cek yang dilengkapi rubrik.

Penilaian kinerja adalah tentang penampilan pengetahuan pada situasi kinerja yang realistis, sebagai pertentangan keluar konteks di ujian sekolah. Penilaian ini digunakan untuk mengevaluasi kemampuan berpikir tingkat tinggi atas penguasaan pengetahuan, konsep, dan keterampilan yang diperlukan untuk keberhasilan peserta didik (Wren, 2009). Stiggins (1987) menyatakan tujuan dari penilaian kinerja menilai kemampuan menerjemahkan pengetahuan dan pemahaman melalui tindakan.

Agar penilaian kinerja tidak berubahubah, maka respon dalam konstruksi peserta didik harus diberikan penskoran (Popham, 
2000). Brookhart (2013) menyatakan bahwa: "the main purpose of rubrics is to assess performances". Tujuan utama dari rubrik adalah menilai kinerja. Bagaimana kita sebagai pengamat mencocokkan kriteria spesifik dengan indikator pencapaian peserta didik. Penskoran respon kriteria adalah salah satu cara menetapkan respon minimal peserta didik, sehingga mereka tahu bagaimana kinerja mereka dievaluasi.

Pada proses pembelajaran, tidak hanya dibutuhkan penilaian pada aspek pengetahuan dan keterampilan. Penilaian afektif juga penting, salah satunya adalah sikap. Menurut Stiggins (1994) sikap adalah bagian dari afektif selain minat, motivasi, nilai, preferensi, konsep diri, dan tempat mengontrol. Sikap bermula dari perasaan suka atau tidak suka terhadap suatu obyek yang berkaitan dengan kecenderungan seseorang dalam merespon sesuatu. Sikap dapat dibentuk kemudian terjadi perilaku yang diinginkan (Ruslan, 2005).

Hasil wawancara pada guru diperoleh informasi bahwa kendala yang dihadapi pada saat melakukan penilaian adalah pada praktikum beberapa sikap tidak terukur dan pedoman penskoran pada aspek pengamatan kinerja sebelumnya tidak ada. Hal ini mengakibatkan sulit bagi guru untuk membandingkan dan memberikan keputusan pada tingkatan mana kompetensi peserta didik berada.

Berdasarkan Peraturan Pemerintah Nomor 19 Tahun 2005 pasal 25 ayat 4 yang menyatakan bahwa kompetensi lulusan mencakup sikap, pengetahuan, dan keterampilan. Dimana pada masing-masing ranah diperlukan suatu instrumen penilaian yang dapat mengukur kemampuan secara spesifik, sehingga guru dapat mengukur sejauh mana tujuan pembelajaran dicapai. Penilaian kinerja adalah penilaian yang menuntut peserta didik memperlihatkan pengetahuan dan pemahamannya dalam bentuk tindakan (Colley, 2008). Penilaian kinerja adalah salah satu dari penilaian yang disarankan kurikulum 2013 yang berlaku saat ini (Kunandar 2014) untuk mengukur ketercapaian kompetensi belajar peserta didik.

Penilaian kinerja sangat membantu dalam penentuan keputusan melalui pengamatan dan tepat digunakan untuk menilai kompetensi peserta didik pada saat praktikum. Ramadani (2012) dan Jumriati (2014) menemukan bahwa penggunaan penilaian kinerja menuntut pengamat dalam mengamati semua aspek yang dimiliki praktikan sehingga keterampilan peserta didik dapat terukur dengan menyeluruh.

SMTI belum menyediakan perangkat penilaian yang digunakan untuk menilai kinerja dan sikap pada praktikum. Sehingga dipandang perlu mengembangkan perangkat penilaian pada aspek tersebut. Perangkat penilaian membantu guru memberikan keputusan tentang hasil kerja peserta didik. Adanya perangkat penilaian membuat peserta didik mengetahui aspek apa saja yang dinilai sehingga peserta didik akan menunjukkan kemampuan mereka secara optimal.

Berdasarkan latar belakang tersebut maka penting untuk mengembangkan perangkat penilaian kinerja dan sikap dengan mengacu pada model pengembangan Plomp dengan pertimbangan bahwa model ini dipandang lebih cocok dengan pengembangan instrumen penilaian karena berorientasi pada produk dan hasil dimana prosedurnya lebih sederhana (Haksani, 2013). Pengembangan model Plomp lebih fleksibel sesuai karakteristik penilaian yang bersifat berkelanjutan dan tidak terpisah dengan kegiatan pembelajaran sehingga dapat dilakukan revisi dan implementasi yang berulang-ulang pada prototipe sampai perangkat memenuhi kualitas kevalidan, reliabilitas, dan kepraktisan.

Berdasarkan masalah di atas maka rumusan masalah dalam penelitian ini antara lain adalah:

1. Bagaimana proses pengembangan perangkat penilaian kinerja dan sikap pada praktikum titrimetri dan gravimetri SMK-SMTI Makassar?

2. Bagaimana kevalidan, reliabilitas, dan kepraktisan perangkat penilaian kinerja 
dan sikap pada praktikum titrimetri dan gravimetri SMK-SMTI Makassar yang dikembangkan?

\section{METODE PENELITIAN}

\section{Jenis Penelitian}

Penelitian ini merupakan penelitian pengembangan yang mengacu pada model pengembangan Plomp.

2. Subyek Uji Coba

Penelitian ini diujicobakan terbatas pada peserta didik kelas X Jurusan Kimia Industri 2 SMK-SMTI Makassar. sebanyak 33 orang serta guru yang mengajar praktikum Dasar Kerja Laboratorium semester genap tahun pelajaran 2014-2015.

3. Instrumen Penelitian

Instrumen penelitian yang digunakan antara lain:

a. Angket respon guru, digunakan untuk memperoleh respon guru tentang kemudahan penggunaan perangkat yang dikembangkan.

b. Lembar validasi instrumen, digunakan untuk memperoleh informasi validitas dan reabilitas perangkat yang dikembangkan.

c. Lembar penilaian kinerja digunakan untuk mendapatkan informasi tentang kinerja peserta didik dalam melakukan analisis titrimetri dan gravimetri.

d. Lembar penilaian sikap, digunakan untuk mendapatkan informasi respon peserta didik dalam melakukan analisis titrimetri dan gravimetri.

4. Teknik Analisis Data

a. Analisis Validitas

Data yang diperoleh dianalisis dengan mempertimbangkan masukan dan saran validator. Kelayakan instrumen menurut Ruslan (2009) merupakan relevansi kedua pakar. Koefisien validitas isi dihitung berdasarkan:

$$
\text { Validitas Isi }=\frac{D}{A+B+C+D}
$$

Selanjutnya melakukan rekapitulasi hasil kesepakatan ahli ke dalam tabel pada setiap butir instrumen. Kemudian menggolongkan hasil kesepakatan penilai ke dalam A, B, C, maupun $\mathrm{D}$ selanjutnya menghitung koefisien validitas isinya. Jika nilai koefisien validitas isi > 0,75 maka instrumen sudah dikatakan valid (Ruslan, 2009). Selanjutnya dapat dilakukan uji coba. Namun, jika tingkat pencapaian validitas belum valid, perlu dilakukan revisi. Selanjutnya dilakukan kembali validasi. Demikian seterusnya sampai diperoleh perangkat yang ideal dari ukuran validitas konstruk dan isinya

b. Analisis Reliabilitas

Reliabilitas adalah konsistensi. Penilaian konsisten apabila perangkat penilaian telah mencapai tujuan yang diinginkan yakni tidak terdapat perbedaan hasil penilaian dari masing-masing penskor (rater). Selanjutnya dilakukan perhitungan dengan analisis Alpha Cronbach pada program $S P S S$. Jika nilai $0,70 \leq \mathrm{r}$, dikatakan instrumen penilaian telah memiliki reliabilitas cukup tinggi (Karyana, 2013).

c. Analisis Kepraktisan

Kepraktisan merupakan salah satu indikator kualitas suatu alat ukur. Perangkat penilaian dikatakan praktis apabila perangkat penilaian dinilai mudah digunakan oleh responden berdasarkan tanggapan guru terhadap perangkat. Dengan melihat aspek seperti kemudahan dalam penggunaan perangkat dan kelengkapan aspek yang dinilai. Hal ini dilakukan dengan cara menghitung banyaknya yang memberi respon positif sesuai aspek yang diminta kemudian menghitung rata-ratanya, dan menentukan kategori dengan kriteria yang ditetapkan.

\section{HASIL PENELITIAN}

1. Validitas

Hasil perhitungan validitas isi dirangkum dalam Tabel 1:

Tabel 1 Deskripsi Validitas Isi Perangkat Penilaian

\begin{tabular}{|c|c|c|c|}
\hline \multicolumn{2}{|r|}{ Penilaian } & $\begin{array}{c}\text { Validitas } \\
\text { Isi }\end{array}$ & Kategori \\
\hline \multirow[t]{2}{*}{ Kinerja } & Analisis Titrimetri & 1,00 & Valid \\
\hline & Analisis Gravimetri & 1,00 & Valid \\
\hline \multirow[t]{3}{*}{ Sikap } & Penilaian Diri & 1,00 & Valid \\
\hline & Penilaian Antar Teman & 1,00 & Valid \\
\hline & $\begin{array}{l}\text { Penilaian Observasi } \\
\text { Sikap }\end{array}$ & 0,89 & Valid \\
\hline \multirow[t]{3}{*}{ Kognitif } & Analisis Titrimetri & 1,00 & Valid \\
\hline & Analisis Gravimetri & 0,83 & Valid \\
\hline & Laporan Praktikum & 1,00 & Valid \\
\hline \multicolumn{2}{|r|}{ Rata-Rata } & 0,965 & Valid \\
\hline
\end{tabular}


2. Reabilitas

Adapun hasil analisis reabilitas tiap perangkat penilaian disajikan Tabel 2:

\begin{tabular}{clcr}
\multicolumn{4}{c}{ Tabel 2 Deskripsi Hasil Perhitungan Reabilitas Perangkat Penilaian } \\
\hline \multirow{3}{*}{ Kinerja } & Penilaian & Koefisien Alpha Cronbach & Kategori \\
\cline { 2 - 4 } & Analisis Titrimetri & 0,813 & Reliabel \\
\cline { 2 - 4 } & Analisis Gravimetri 1 & 0,726 & Reliabel \\
\cline { 2 - 4 } & Analisis Gravimetri 2 & 0,741 & Reliabel \\
\hline \multirow{3}{*}{ Sikap } & Penilaian Diri & 0,838 & Reliabel \\
\cline { 2 - 4 } & Penilaian Antar Teman & 0,838 & Reliabel \\
\cline { 2 - 4 } & Penilaian Observasi Sikap & 0,897 & Reliabel \\
\hline \multirow{3}{*}{ Kognitif } & Analisis Titrimetri & 0,784 & Reliabel \\
\cline { 2 - 4 } & Analisis Gravimetri & 0,914 & Reliabel \\
\cline { 2 - 4 } & Laporan Praktikum & 0,741 & Reliabel \\
\hline & Rata-Rata & 0,307 & Reliabel \\
\hline
\end{tabular}

3. Kepraktisan

Adapun hasil penyebaran angket respon guru disajikan dalam Tabel 3:

\begin{tabular}{|c|c|c|c|c|c|c|c|}
\hline \multirow{2}{*}{\multicolumn{2}{|c|}{ Perangkat Penilaian }} & \multicolumn{4}{|c|}{ Jumlah Skor Penilai } & \multirow{2}{*}{$\begin{array}{l}\text { Rata- } \\
\text { Rata } \\
\text { Skor }\end{array}$} & \multirow{2}{*}{ Kategori } \\
\hline & & 1 & 2 & 3 & 4 & & \\
\hline \multirow{3}{*}{ Kinerja } & Analisis Titrimetri & 60 & 68 & 58 & 70 & 64,00 & Praktis \\
\hline & Analisis Gravimetri 1 & 60 & 70 & 58 & 70 & 64,50 & Praktis \\
\hline & Analisis Gravimetri 2 & 60 & 68 & 70 & 72 & 67,50 & $\begin{array}{l}\text { Sangat } \\
\text { Praktis }\end{array}$ \\
\hline \multirow{3}{*}{ Kognitif } & Analisis Titrimetri & 60 & 68 & 58 & 70 & 64,00 & Praktis \\
\hline & Analisis Gravimetri & 60 & 69 & 58 & 70 & 64,00 & Praktis \\
\hline & Laporan Praktikum & 60 & 72 & 58 & 70 & 65,00 & $\begin{array}{l}\text { Sangat } \\
\text { Praktis }\end{array}$ \\
\hline \multirow{4}{*}{ Sikap } & Penilaian Diri & 60 & 72 & 58 & 70 & 65,00 & $\begin{array}{l}\text { Sangat } \\
\text { Praktis }\end{array}$ \\
\hline & $\begin{array}{l}\text { Penilaian Antar } \\
\text { Teman } \\
\end{array}$ & - & - & - & - & - & - \\
\hline & Observasi Sikap & 60 & 72 & 58 & 70 & 65,00 & $\begin{array}{l}\text { Sangat } \\
\text { Praktis }\end{array}$ \\
\hline & Rata-Rata & 60 & 69,37 & 59,5 & 70,25 & 64,87 & Praktis \\
\hline
\end{tabular}

\section{PEMBAHASAN}

\section{Pengembangan Perangkat Penilaian \\ a. Tahap Investigasi Awal}

Pada tahap investigasi awal, hal yang dilakukan adalah menghimpun informasi mengenai kondisi yang mempengaruhi pengembangan perangkat penilaian yang dilakukan dengan wawancara dan observasi langsung. Berdasarkan hasil wawancara diperoleh bahwa penilaian kurikulum 2013 menyulitkan guru dalam membuat penilaian yang autentik kemudian tuntutan standar kelulusan yang lebih mengutamakan keahlian, keterampilan, dan sikap mereka dalam dunia kerja memerlukan suatu alat ukur yang disesuaikan dengan karakteristik mutu lulusannya.

Penilaian yang diharapkan pada kurikulum 2013 adalah penilaian yang menekankan pada proses pembelajaran. Penilaian yang selama ini dilakukan adalah dengan menilai laporan praktikum untuk menilai pengetahuan dan penilaian diri untuk mengetahui keterampilan analisis peserta didik. Adapun untuk penilaian sikap dilihat dari kehadiran peserta didik dalam kegiatan analisis. Hal ini kurang sesuai dengan kurikulum 2013 yang menekankan pada penguatan proses dalam menilai keterampilan dan pengetahuan yang terkait dengan kompetensi yang diharapkan.

Terdapat kelemahan dalam menilai kinerja dengan penilaian diri yakni tingginya unsur subyektivitas penilai. Hal ini terjadi jika kriteria tidak disertai dengan rubrik penskoran. Sebelumnya penilaian keterampilan dilakukan hanya memperlihatkan indikator apa saja yang harus dikuasai peserta didik tetapi penilaiannya tidak disertai rubrik penskora. Poin penting dalam perbaikan penilaian di sekolah ini adalah diperlukan suatu rubrik penilaian yang berisi kinerja dasar dalam mengukur kinerja peserta didik. Selain itu, urutan penilaian perlu disesuaikan dengan urutan proses analisis. Hal ini dimaksudkan agar memudahkan guru dalam merekam dan memberikan keputusan pada level mana keterampilan peserta didiknya.

Selain kinerja dalam analisis, hal yang tidak kalah penting adalah bagaimana menilai afektif peserta didik. Dalam ranah afektif komponen yang telah banyak diukur adalah sikap. Beberapa sikap peserta didik sulit diamati dalam praktikum namun bukan berarti tidak dapat diukur sama sekali. Hal ini dapat dilakukan melalui pengisian angket skala sikap. Sehingga menjadikan kehadiran sebagai patokan untuk melihat baik atau tidaknya sikap peserta didik adalah kurang tepat.

Berdasarkan identifikasi dan analisis informasi yang dilakukan, maka sangat diperlukan suatu alat ukur yang dapat membedakan kemampuan peserta didik pada saat praktikum khususnya dalam kinerja dan sikap. Praktikum yang dilaksanakan pada semester genap kelas $\mathrm{X}$ yakni analisis kuantitatif meliputi analisis titrimetri dan gravimetri. Sehingga kinerja dan sikap yang diukur juga dibatasi hanya yang terlihat dalam analisis titrimetri maupun gravimetri. 


\section{b. Tahap Perancangan}

Pada tahap perancangan kegiatan yang dilakukan adalah melakukan beberapa kegiatan dimulai dengan membuat matriks hubungan kinerja dan sikap dengan prosedur kerja, kemudian memilih format dan bentuk penilaian. Selanjutnya menentukan skor untuk skala penilaian. Kemudian mendaftarkan aspek penilaian dalam kisikisi. Dan menjabarkan kisi-kisi intrumen penilaian sikap menjadi indikator sikap ilmiah dan sikap sosial. Selanjutnya membatasi aspek penilaian menjadi sikap yang dapat teramati saat praktikum. Kemudian merakit pernyataan berdasarkan indikator sikap yang dibuat menjadi pernyataan positif maupun negatif.. Kemudian membuat lembar validasi penilaian kinerja dan sikap, serta angket respon guru.

\section{c. Tahap Realisasi}

Kegiatan yang dilakukan pada tahap ini adalah membuat draft penilaian kinerja maupun sikap dalam analisis titrimetri maupun gravimetri yang terdiri dari:

1) Hasil rancangan awal instrumen penilaian kinerja

Penilaian kinerja yang peneliti kembangkan dimulai dari tahap persiapan praktikum hingga saat selesai praktikum. Sehingga dalam analisis titrimetri dan gravimetri masing-masing aspek pengamatan yang akan dinilai ada 10 aspek.

2) Hasil rancangan awal instrumen penilaian sikap

Adapun dalam penilaian sikap kegiatan yang dilakukan adalah membuat tiga penilaian yakni penilaian yang dilihat dari peserta didik yaitu penilaian diri dan penilaian antar teman serta penilaian yang dilihat dari segi guru yaitu pengamatan sikap. Penilaian diri dan penilaian teman sejawat berbentuk skala likert dengan masing-masing 28 butir pernyataan. Adapun penilaian sikap secara observasi berisi 7 indikator untuk mengukur sikap ilmiah dan sosial.

3) Hasil rancangan awal instrumen penilaian kognitif
Penilaian kognitif berbentuk tes uraian dengan pertimbangan bahwa dalam tes uraian kemampuan peserta didik yang sebenarnya dapat terungkap. Dalam tes uraian, lebih mudah mendeteksi kecurangan peserta didik. Terdapat kekurangan tes uraian yakni adanya unsur subyektivitas dari penilai dan untuk menghindari subyektivitas maka rubrik penskoran disiapkan pada masing-masing analisis.

\section{d. Tahap Tes, Evaluasi, dan Revisi}

Sebelum perangkat penilaian diujicobakan, terlebih dahulu diperiksa kesesuaiannya dengan teori oleh pakar dibidangnya masing-masing. Analisis secara teoritik mempertimbangkan masukan, saran, dan komentar dari kedua validator. Dalam hal ini perangkat penilaian diperiksa oleh validator yang ahli dalam bidang evaluasi dan kimia analisis.

1) Validitas isi

Validitas isi dilakukan melalui penelaahan kisi-kisi tes untuk memastikan bahwa soal-soal telah mencerminkan keseluruhan konten maupun materi yang seharusnya dikuasai secara proporsional (Djaali, 2008). Validitas isi didasarkan pada pendapat para ahli dalam bidang yang bersangkutan.

2) Hasil Revisi Perangkat Penilaian

a) Penilaian Kinerja

Hasil revisi perangkat penilaian dalam penilaian kinerja lebih banyak ditekankan pada logis tidaknya kalimat pada naskah. Misalnya pada urutan pada rubrik yang sebelumnya tidak sama dengan pada aspek pengamatan, hal ini dikhawatirkan akan membuat guru sebagai penilai keliru dalam memberikan skor pada peserta didiknya. Validator juga memberikan saran pada cara menimbang perlu ditambahkan aspek menstandarkan neraca, teknik membaca skala buret perlu ditambahkan pembacaan skala awal maupun akhir, serta lebih memperhatikan atribut pengamatan pada rubrik penilaian.Dalam penilaian kinerja analisis titrimetri, peneliti melakukan reduksi aspek penilaian dari 10 aspek menjadi 9 aspek. Adapun aspek yang direvisi adalah menggabungkan aspek 
penilaian mengeluarkan titran dan melihat perubahan warna dipandang kurang operasional sehingga peneliti merevisinya menjadi teknik menitrasi.

Adapun dalam analisis gravimetri maka dilakukan reduksi pada aspek mereaksikan contoh garam direvisi menjadi cara mengendapkan dengan pertimbangan karena tujuan mereaksikan contoh garam adalah untuk mendapatkan endapan, aspek cara mengeringkan endapan, memijarkan dan mengabukan endapan digabungkan, dan aspek menghitung endapan yang terbentuk dihilangkan karena dipandang menjadi aspek penilaian dalam laporan praktikum. Sehingga jika pada tahap realisasi aspek pengamatan analisis gravimetri 10 aspek kemudian setelah revisi menjadi 9 aspek pengamatan.

b) Penilaian Sikap

Adapun saran dari validator dalam penilaian sikap adalah mereduksi sikap yang diukur karena melihat indikator sikap terlalu banyak. Mengenai pedoman penskoran untuk penyataan positif maupun negatif tidaklah sama karena sikap adalah kecenderungan peserta didik. Dalam penilaian sikap juga diakukan revisi dalam penilaian diri dan penilaian antar teman. Jika sebelumnya sikap ilmiah yang ingin diukur yakni 12 sikap dan 2 sikap sosial, peneliti mempertimbangkan saran validator bahwa peserta didik akan merasa bingung karena aspek penilaiannya terlalu banyak. Hal ini juga dilakukan pada penilaian observasi sikap.

\section{c) Penilaian Kognitif}

Berdasarkan saran dan masukan dari validator, maka revisi penilaian kognitif dilakukan. Beberapa diantaranya yaitu istilah tes hasil pembelajaran direvisi menjadi tes hasil belajar, "bagaimana perubahan warna dari indikator metil orange?" direvisi menjadi "bagaimana perubahan warna dari indikator metil orange?", menyertakan massa atom relatif masing-masing unsur, serta menyertakan pedoman penskoran untuk alternatif jawaban peserta didik yang sebelumnya tidak ada yang berisikan kemungkinan jawaban peserta didik disertai dengan skornya.

3) Reabilitas

Perhitungan reabilitas menggunakan analisis Alpha Cronbach pada program SPSS for windowns 20 dengan nilai rata-rata koefisien reabilitas adalah 0,807 .

4) Kepraktisan

Analisis kepraktisan diperoleh dari data angket respon guru yang meliputi penilaian format penulisan, bahasa, isi, dan penggunaan perangkat penilaian. Adapun dari segi format, bahasa, isi, dan penggunaan perangkat penilaian, empat orang guru memberikan respon yang positif. Pada indikator petunjuk pengisian dan pengerjaan perangkat penilaian rata-rata hasil angket respon guru adalah 3.11; jenis dan ukuran huruf 3,53; tata letak 3,53; penggunaan Bahasa Indonesia 3,13; tulisan, ejaan, dan tanda baca 3,22; kesesuaian isi dengan indikator dan KD 3,02; perbedaan tingkatan kualitas 3,53 ; praktis dan ekonomis 3,03; efisien 3,00; dan dampak penggunaan perangkat bagi guru 3,14.

\section{e. Tahap Implementasi}

1. Uji Coba Terbatas

Adapun dalam tahap uji coba lapangan dapat dijelaskan sebagai berikut:

a) Penilaian Kinerja Analisis Titrimetri

Guru sebagai penilai merasa kesulitan membedakan peserta didiknya karena atribut kritis pada aspek penilaian cara menimbang menurut mereka kurang operasional sehingga menyarankan atribut kritis ini direvisi. Selain itu pada aspek cara membersihkan area kerja yang telah digunakan guru menilai atribut kritis membersihkan meja saja tidak cukup namun perlu disesuaikan dengan peraturan laboratorium pada sekolah tersebut. Adapun hasil revisi perangkat penilaiannya menjadi membersihkan meja menggunakan lap basah serta mengembalikan bahan yang masih dapat digunakan ulang pada tempatnya.

b) Penilaian Kinerja Analisis Gravimetri

Tidak berbeda dengan uji coba penilaian titrimetri menurut guru menilai aspek cara menimbang kurang operasional sehingga guru menyarankan perlu direvisi. 
Selain itu pada aspek cara membersihkan area kerja yang telah digunakan hasil revisi perangkat penilaiannya menjadi membersihkan meja menggunakan lap basah serta mengembalikan bahan yang masih dapat digunakan ulang pada tempatnya.Peralatan dalam uji coba analisis tidak sesuai dengan yang ada di atribut kritis perangkat penilaian, sehingga pada aspek penilaian cara menyaring endapan menggunakan corong gelas, statif dan klem yang digunakan untuk menyangga corong diganti menjadi kaki tiga dan segitiga porselin.

c) Penilaian Sikap

Dalam mengujicobakan penilaian sikap, uji coba hanya dilakukan pada penilaian diri dan observasi penilaian sikap. Pertimbangan untuk tidak mengujicobakan penilaian teman sejawat karena selama analisis berlangsung, peserta didik melakukan penetapan secara individu mulai awal hingga selesai penetapan sehingga tidak mungkin dapat mengamati teman lain dengan seksama.

\section{1) Penilaian diri}

Dalam penilaian diri, peneliti ingin peserta didik secara sadar dapat berpartisipasi menilai dirinya sendiri dan menjadi bahan refleksi nantinya. Data yang diperoleh sama untuk penilaian diri peserta didik dalam analisis titrimetri maupun gravimetri. Peserta didik tampaknya konsisten dengan pendapatnya mengenai sikap mereka.

2) Penilaian observasi sikap

Sikap peserta didik dinilai berdasarkan pengamatan guru pada saat praktikum sehingga aspek penilaian sikap hanya dibatasi pada aspek yang mudah diamati pada saat praktikum di laboratorium.

d) Penilaian Kognitif

Penilaian kognitif, baik analisis titrimetri maupun gravimetri tidak diujicobakan karena keterbatasan waktu penelitian yang diberikan. Di samping itu, penilaian kognitif diujikan pada mata pelajaran lain. Dalam penilaian laporan praktikum, peneliti mengujicobakan pada laporan gravimetri yang berjudul penentuan air hablur garam terusi dan penentuan kadar tembaga dalam kristal terusi.

2. Revisi dalam Tahap Uji Coba

Dalam mengimplementasikan perangkat penilaian kinerja dan sikap analisis titrimetri dan gravimetri beberapa revisi dilakukan. Revisi ini berdasarkan hasil diskusi dan pertimbangan peneliti dengan guru yang mengajar. Revisi ini dilakukan pada atribut kritis beberapa aspek penilaian. Seperti urutan dalam membilas alat gelas, dan menambahkan atribut kritis mengembalikan bahan kimia yang masih dapat digunakan pada tempatnya dan membuang bahan yang tidak dapat digunakan serta membersihkan meja dengan lap basah pada cara membersihkan area kerja yang telah digunakan pada penilaian kinerja analisis titrimetri.

Pada analisis gravimetri, revisi dilakukan dilakukan pada atribut kritis beberapa aspek penilaian. Seperti urutan dalam membilas alat gelas, menambahkan atribut kritis mengecek posisi waterpass, merevisi menggunakan kaki tiga dan segitiga porselin untuk menyangga corong dalam menyaring endapan, dan menambahkan atribut kritis mengembalikan bahan kimia yang masih dapat digunakan pada tempatnya dan membuang bahan yang tidak dapat digunakan serta membersihkan meja dengan lap basah pada cara membersihkan area kerja yang telah digunakan pada penilaian kinerja analisis titrimetri.

3. Penyebaran Produk

Perangkat penilaian kinerja juga disebarkan pada sekolah yang memiliki karakteristik hampir sama dengan sekolah tempat mengujicobakan prototipe 1 dengan mengambil sampel dua guru dari sekolah yang bersangkutan kemudian mengumpulkan informasi dengan memberikan angket respon guru dan perangkat penilaian. Rrata-rata hasil angket respon guru pada penyebaran produk adalah 69,56 dengan kategori sangat praktis sehingga perangkat penilaian kinerja dan sikap pada praktikum titrimetri dan 
gravimetri dapat disebarkan pada sekolah ini.

\section{Kualitas Perangkat Penilaian}

a. Validitas

Seluruh perangkat penilaian kinerja maupun sikap berada dalam ketegori valid karena nilai validitasnya diatas 0,75 . Adapun hasil rata-rata nilai validitas isi adalah 0,965. Djaali dan Muljono (2008) berpendapat bahwa nilai validitas isi telah mencerminkan keseluruhan konten yang seharusnya dikuasai secara proporsional dilihat dari pendapat pakar atau ahli.

b. Reabilitas

Nilai reabilitas diperoleh dari skor yang diberikan guru pada lembar validasi perangkat penilaian. Berdasarkan nilai koefisien Alpha Cronbach dengan bantuan program SPSS 20 for windons semua perangkat penilaian untuk analisis titrimetri dan gravimetri berada pada kategori reliabel karena nilai koefisien lebih besar dari 0,70 dengan hasil rata-rata 0,807 . Sehingga dapat ditarik kesimpulan perangkat penilaian kinerja dan sikap ini memiliki tingkat stabilitas atau konsistensi yang tinggi.

c. Kepraktisan

Angket respon guru diberikan kepada empat guru yang dianggap memahami praktikum titrimetri dan gravimetri. Hasil pengisian angket selanjutnya dilakukan perhitungan rata-rata jumlah skor penilai. Nilai rata-rata ini kemudian digolongkan berdasarkan kategori dan hasil nilai rata-rata kepraktisan adalah 64,87 atau berada pada kategori praktis sehingga perangkat penilaian kinerja dan sikap ini dapat digunakan dengan mudah dalam menilai analisis titrimetri dan gravimetri.

\section{KESIMPULAN}

Berdasarkan analisis hasil dan pembahasan, maka dapat disimpulkan bahwa:

1. Proses pengembangan perangkat penilaian kinerja dan sikap dilakukan dengan lima tahapan yakni tahap investigasi awal yang dilakukan melalui kegiatan mengidentifikasi informasi, analisis informasi, membatasi masalah dan merencanakan kegiatan lanjutan; tahap perencanaan yang dilakukan melalui kegiatan perancangan penilaian kinerja dan sikap dalam bentuk penyusunan kisi-kisi penilaian kinerja maupun sikap; tahap realisasi atau konstruksi yang dilakukan dengan pembuatan draft awal penilaian kinerja dan sikap; tahap evaluasi, tes, dan revisi dilakukan dengan validasi isi; serta tahap implementasi dilakukan dengan kegiatan uji coba terbatas.

2. Perangkat penilaian kinerja dan sikap pada praktikum titrimetri dan gravimetri SMK-SMTI Makassar yang dikembangkan menunjukkan perangkat penilaian memenuhi kriteria valid, reliabel, dan praktis. Adapun nilai ratarata kevalidan, reliabilitas, dan kepraktisan berturut-turut adalah 0,965; 0,807; dan 64,87.

DAFTAR PUSTAKA.

Arends, R.I. 2008. Learning To Teach (Belajar Untuk Mengajar) Edisi Ketujuh Jilid I. Yogyakarta: Pustaka Pelajar.

Brookhart, S.M. 2013. How to Create and Use Rubrics for Formative Assessment and Grading. Virginia: ASCD United States of America.

Colley, K. 2008. Performance-Based Assessment. The Science Teacher, November 2008. Halaman 68-72.

Djaali \& Muljono. 2008. Pengukuran dalam Bidang Pendidikan. Jakarta: Grasindo.

Haksani. 2013. Pengembangan Perangkat Asssessment Berbasis Keterampilan Generik Sains pada Mata Kuliah Praktikum Kimia Dasar Lanjut. Jurnal Chemica, Vol.14, No.1, 27 37

Husamah. 2013. Desain Pembelajaran Berbasis Pencapaian Kompetensi (Panduan Merancang Pembelajaran untuk Mendukung Implementasi Kurikulum 2013). Jakarta: Prestasi Pustaka. 
Jumriati. 2014. Pengembangan Perangkat Penilaian Kinerja Berbasis Keterampilan Proses Sains Pada Praktikum Kimia. Tesis. Tidak diterbitkan. Makassar: Program Pascasarjana Universitas Negeri Makassar.

Karyana, I,K. 2013. Pengembangan Instrumen Penilaian Unjuk Kerja (Performance Assessment) Keterampilan Penerapan Metode Ilmiah dalam Penyusunan Skrip Karya Seni Mahasiswa Program Studi Seni Rupa Murni Institut Seni Indonesia Denpasar. Jurnal Seni Budaya Mudra, Volume 28, No.2, $216-229$.

Kemendikbud. 2014. Buku Teks Bahan Ajar Siswa Paket Keahlian: Kimia Analisis, Teknik Dasar Pekerjaan Laboratorium Kimia. Jakarta: Direktorat Pembinaan SMK.

Kunandar. 2014. Penilaian Autentik, Penilaian Hasil Belajar Peserta Didik Berdasarkan Kurikulum 2013. Jakarta: Rajawali Press.

Popham, J. 2000. Classroom Assessment, What Teacher Need to Know Sixth Edition. Los Angeles: University of California.

Ramadani, K. 2012. Pengembangan Perangkat Penilaian Kinerja Pada Praktikum Kimia Dasar Lanjut. Tesis. Tidak diterbitkan. Makassar: Program Pascasarjana Universitas Negeri Makassar.

Ruslan. 2005. Prinsip Dasar Evaluasi (Disampaiakan pada Diklat Guru Sekolah Dasar Mata Pelajaran Matematika). Makassar: Lembaga Penjamin Mutu Pendidikan Sulawesi Selatan.

Ruslan. 2009. Validitas Isi. Buletin Pa'biritta, No.10 Tahun VI. Halaman 19.

Stiggins, R.J.1987. Design and Development of Performance Assesments. Northwest Regional educational Laboratory. Online. (http://onlinelibrary.wiley.com/doi/1
$0.1111 / \mathrm{j} .1745-$

3992.1987.tb00507.x/pdf, Diakses tanggal 2 Desember 2014).

Stiggins, R.J. 1994. Student-Centered Classroom Assessment. New York: Macmillan Publishing Company.

Sunarti. 2014. Penilaian dalam Kurikulum 2013 (Membantu Guru dan Calon Guru Mengetahui 